\title{
THE MODEL OF PSYCHOPATHOGENESIS OF NONPSYCHOTIC MENTAL DISORDERS IN PERSONS UNDERGOING THE PROGRAMS OF SYNTHETIC OPIOIDS SUBSTITUTION THERAPY
}

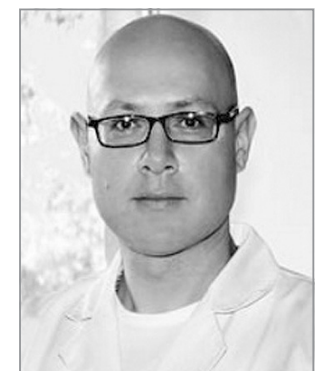

V. V. Chugunov

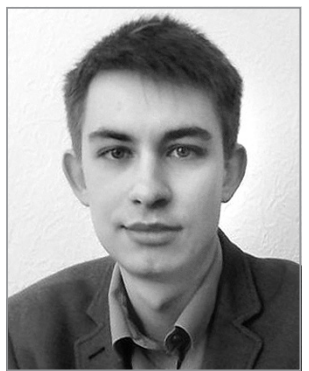

A. D. Gorodokin

(C) Vadim Chugunov (Ukraine) - MD, PhD in Medicine (doctor of medical sciences), Professor; Head of the Department of Psychiatry, Psychotherapy, General and Medical Psychology, Narcology and Sexology of Zaporizhzhia State Medical University; 26 Mayakovsky avenue, Zaporizhzhia, 69035; e-mail: NULP_board@ukr.net; ORCID: 0000-0002-1141-8184.

(с) Чугунов Вадим Віталійович (Україна) - д.мед.н. професор; завідувач кафедрою психіатрії, психотерапії, загальної та медичної психології, наркології та сексології Запорізького державного медичного університету, пр. Маяковського, 26, м. Запоріжжя, 69035; e-mail: NULP_board@ukr.net; ORCID: 0000-0002-1141-8184.

(c) Чугунов Вадим Витальевич (Україна) - д.мед.н. профессор; заведующий кафедрой психиатрии, психотерапии, общей и медицинской психологии, наркологии и сексологииЗапорожского государственного медицинского университета, пр. Маяковского, 26, г. Запорожье, 69035; e-mail: NULP_board@ ukr.net; ORCID: 0000-0002-1141-8184.

(C) Anton Gorodokin (Ukraine) - MD, Master of Psychiatry, postgraduate student of the Department of Psychiatry, Psychotherapy, General and Medical Psychology, Narcology and Sexology of Zaporizhzhia State Medical University; 26 Mayakovsky avenue, Zaporizhzhia, 69035; e-mail: antongorodokin@gmail.com; 0RCID: 0000-0003-1724-0767. (c) Городокін Антон Дмитрович (Україна) - магістр психіатрії, аспірант кафедри психіатрії, психотерапії, загальної та медичної психології, наркології та сексології Запорізького державного медичного університету, пр. Маяковського, 26, м. Запоріжжя, 69035; e-mail: antongorodokin@gmail.com; 0RCID: 0000-0003-1724-0767.

(c) Городокин Антон Дмитриевич (Україна) - магистр психиатрии; аспирант кафедры психиатрии, психотерапии, общей и медицинской психологии, наркологии и сексологии Запорожского государственного медицинского университета, пр. Маяковского, 26, г. Запорожье, 69035; e-mail: antongorodokin@gmail.com; ORCID: 0000-0003-1724-0767.

№ 9, 2018, p. 60-65

THE MODEL OF PSYCHOPATHOGENESIS OF NONPSYCHOTIC MENTAL DISORDERS IN PERSONS UNDERGOING THE PROGRAMS OF SYNTHETIC OPIOIDS SUBSTITUTION THERAPY

Abstract. In order to identify the structural and dynamic characteristics of comorbid non-psychotic psychopathological symptoms in patients on the synthetic opioid substitution therapy program, 100 patients of the narcological dispensary were examined with the help of the Simptom Check List - 90 - Revised. The study used the inclusion and exclusion criteria that are identical to the criteria for participation in the substitution therapy program. The results were distributed to 3 levels, which correspond to the degree of clinical significance of the symptoms: - minimal (discomfort for this reason occurs rarely or does not occur at all, it has a low intensity) - the range of results obtained is from 0 to 0.50 ; - subclinical (the presence of not frequent, moderately intense discomfort for this reason) - the range of values is from 0.51 to 1.50 ; - clinical (frequent or persistent high intensity discomfort for this reason) - range of values greater than 1.51. The study found that non-psychotic mental disorders among this group of patients have three stages of development. All groups of symptoms are considered in the context of the three main classes of disorders (patho-affective - anxiety and depression symptoms; pseudo-neurotic - obsessivecompulsive phenomena; psycho-vegetative symptoms and self-perception disorders; and psychoorganic - associative disorders, paranoia and hostility) and two groups of intermediate symptoms (phobic — intermediate between pathogenic and pseudoneurotic and psychotic - intermediate between psychoorganic and pseudoneurotic). Also, according to the results of the assessment of the correlation dynamics of symptom groups, a model of psycho-pathogenesis of non-psychotic mental disorders in people who are on the program of drug addiction substitution therapy was constructed.

Key words: $\quad$ replacement therapy, methadone, neurotic disorders, narcology.

МОДЕЛЬ ПСИХОПАТОГЕНЕЗА НЕПСИХОТИЧЕСКИХ ПСИХИЧЕСКИХ РАССТРОЙСТВ У ЛИЦ, ПРОХОДЯЩИХ ПРОГРАММУ СИНТЕТИЧЕСКОЙ ОПИОИДНОЙ ЗАМЕСТИТЕЛЬНОЙ ТЕРАПИИ.

Аннотация. $\quad$ С целью выявления структурно-динамической характеристики коморбидной непсихотической психопатологической симптоматики у больных, находящихся на программе заместительной терапии синтетическими опиоидами, при помощи Симптоматического опросника (Simptom Check List-90-Revised) было обследовано 100 пациентов наркологического диспансера. В исследовании использованы критерии включения и исключения, идентичные критериям участия в программе заместительной терапии. 
Полученные результаты были распределены на 3 уровня, которые соответствуют степени клинической значимости симптомов: - минимальный (дискомфорт по этой причине происходит редко или вообще не возникает, он имеет низкую интенсивность) диапазон полученных результатов от 0 до 0,50; - субклинический (наличие не частого, умеренно интенсивного дискомфорта по данной причине) - диапазон значений от 0,51 до 1,50; - клинический (частый или постоянный высокой интенсивности дискомфорт по этой причине) - диапазон значений болеее 1,51. В результате исследования было обнаружено, что непсихотические психические расстройства среди данного контингента больных имеют три этапа развития; все группы симптомов рассматриваются в контексте трех основных классов расстройств (патоаффективные - симтомы тревожности и депрессии, псевдоневротические - обсессивно-компульсивные явления, психовегетативные симптомы и нарушения самовосприятия и психоорганические - ассоциативные нарушения, паранояльность и враждебность) и двух групп промежуточных симптомов (фобические - промежуточные между патогенными и псевдоневротическими и психотические - промежуточные между психоорганическими и псевдоневротическими). Так же по результатам оценки корреляционной динамики групп симптомов была построена модель психопатогенеза непсихотических психических расстройств у лиц, находящихся на программе заместительной терапии наркомании.

Ключевые слова: заместительная терапия, метадон, невротические расстройства, наркология.

МОДЕЛЬ ПСИХОПАТОГЕНЕЗУ НЕПСИХОТИЧНИХ ПСИХІЧНИХ РОЗЛАДІВ У ОСІБ, ЯКІ ПРОХОДЯТЬ ПРОГРАМУ СИНТЕТИЧНОї ОПІОІДНОї ЗАМІСНОї ТЕРАПIї.

Анотація.

3 метою виявлення структурно-динамічної характеристики коморбидної непсихотичної психопатологічної симптоматики у хворих, які перебувають на програмі замісної терапії синтетичними опіоїдами, за допомогою симптоматичного опитувальника (Simptom Check List-90-Revised) було обстежено 100 пацієнтів наркологічного диспансеру. У дослідженні використані критерії включення і виключення, ідентичні критеріям участі в програмі замісної терапії. Отримані результати були розподілені на 3 рівня, які відповідають ступеню клінічної значущості симптомів: - мінімальний (дискомфорт з цієї причини відбувається рідко або взагалі не виникає, він має низьку інтенсивність) - діапазон отриманих результатів від 0 до 0,50; - субклінічний (наявність не частого, помірно інтенсивного дискомфорту через це) - діапазон значень від 0,51 до 1,50; - клінічний (частий або постійний високої інтенсивності дискомфорт з цієї причини) - діапазон значень більше 1,51. В результаті дослідження було виявлено, що непсихотичні психічні розлади серед даного контингенту хворих мають три етапи розвитку; всі групи симптомів розглядаються в контексті трьох основних класів розладів (патоафектівні - симптоми тривожністі і депресії, псевдоневротичні - обсесивно-компульсивні явища, психовегетативні симптоми і порушення самосприйняття і психоорганічні - асоціативні порушення, паранояльність і ворожість) та двох груп проміжних симптомів (фобічні - проміжні між патогенними і псевдоневротичними і психотичні - проміжні між психоорганічними і псевдоневротичними). Так само за результатами оцінки кореляційної динаміки груп симптомів була побудована модель психопатогенезу непсихотичних психічних розладів у осіб, які перебувають на програмі замісної терапії наркоманії.

Ключові слова: замісна терапія, метадон, невротичні розлади, наркологія.

\section{Introduction}

Among a wide range of psychopathological aspects of the participation of addicted persons in the programs of synthetic opioids substitution therapy, one of the main issues is the diagnostics of non-psychotic psychopathological which are imitating neurotic spectrum violations $[1 ; 2]$. This contingent, due to its medical and social status, is prone to the intense influence of psycho-traumatic factors that involved in the interaction with the altered personality background. At the same time, the possibility of a typical neurotic disorders development in this group of people at the present time is still under discussion $[3 ; 4]$.

The main thesis is the necessity to differentiate between two groups of psychopathological disorders - neurotic ones, the development of which in persons with opioid addiction is doubtful due to damage to the mechanisms of the implementation of psychogenic factors, and neurosis or pseudoneurotic ones, which is a consequence of organic and personality disorders and is manifested by symptoms that are structurally identical to neurotic [5].

Opioid addiction is a factor that massively distorts the essential stereotypes of personality response to a stress and distress, both on psychological, psychosocial and behavioral, and in neuro-metabolic levels [6; 7]. This allows us to consider the contingent of persons undergoing the substitution therapy programs as a homogeneous model for studying the mechanisms of the relationship between chemical dependencies and psychopathological disorders of the neurotic or pseudo-neurotic group [8;9].

\section{Purpose and objectives of the study}

The aim is the establishment of structural and dynamic characteristics of the comorbid nonpsy- 
Table 1

Distribution of different groups of psychopathological symptoms (according SCL-90-R data)

\begin{tabular}{|c|c|c|c|c|c|c|c|c|c|}
\hline \multirow{2}{*}{$\begin{array}{l}\text { SCL-90-R } \\
\text { subscale }\end{array}$} & \multicolumn{3}{|c|}{$\mathrm{GPI} \leq 0,5(\mathrm{~N}=12)$} & \multicolumn{3}{|c|}{$\mathrm{GPI}=0,51-1,50(\mathrm{~N}=52)$} & \multicolumn{3}{|c|}{$\mathrm{GPI} \geq 1,51(\mathrm{~N}=36)$} \\
\hline & M & SC & $\mathrm{C}$ & $M$ & SC & $\mathrm{C}$ & M & SC & C \\
\hline SOM & 8 & 4 & - & 3 & 30 & 19 & - & 16 & 20 \\
\hline O-C & 7 & 5 & - & 4 & 46 & 2 & - & 20 & 16 \\
\hline INT & 9 & 3 & - & 16 & 36 & - & 3 & 15 & 18 \\
\hline DEP & 10 & 2 & - & 2 & 43 & 7 & - & 5 & 31 \\
\hline ANX & 10 & 2 & - & 12 & 39 & 1 & - & 6 & 30 \\
\hline HOS & 5 & 6 & 1 & 9 & 36 & 7 & - & 8 & 28 \\
\hline PHOB & 12 & - & - & 40 & 8 & 4 & 1 & 12 & 23 \\
\hline PAR & 7 & 5 & - & 14 & 32 & 6 & - & 10 & 26 \\
\hline PSY & 11 & 1 & - & 24 & 25 & 3 & - & 16 & 20 \\
\hline
\end{tabular}

Note: $\quad M$-minimal level; SC-subclinical level; C-clinical level.

chotic psychopathological symptoms, in persons who are undergoing the synthetic opioids substitution therapy programs.

The research is conducted in a prospective design. The contingent was formed by a continuous sampling method. In Zaporizhzhya Regional Clinical Narcological Dispensary 100 addicted patients undergoing substitution therapy based on methadone treatment were screened. The study uses the inclusion and exclusion criteria identical to those for participation in the substitution therapy program.

\section{Materials and methods}

The research uses psychopathological method: "Simptom Check List-90-Revised" (L. Derogatis et al, 1973) to establish the structure of psychopathological manifestations at the level of individual symptoms, to identify the correla- tion between them and to establish a general level of psychopathological distress.

In order to level the impact of the narcotic effect or possible manifestations of withdrawal status on the evaluation results, the questionnaire was completed in a 6-8 hours after taking methadone.

The assessment of the intensity of psychopathological symptoms was carried out using ranges of mean-arithmetic scores for each questionnaire subscale, which corresponds to the standard method.

The obtained data were ranked in 3 levels, corresponding to the degrees of clinical significance of the symptoms:

minimal (discomfort for this reason occurs rarely, or does not occur at all, it has a low

Correlation matrix for groups of psychopathological symptoms (according to SCL-90-R)

Table 2 for the subgroup of persons with $\mathrm{GSI} \leq 0,5$

\begin{tabular}{|r|r|r|r|r|r|r|r|r|r|}
\hline & SOM & O-C & INT & DEP & ANX & HOS & PHOB & PAR & PSY \\
\hline SOM & 1,00 & & & & & & & & \\
\hline O-C & 0,50 & 1,00 & & & & & & & \\
\hline INT & $-0,01$ & 0,02 & 1,00 & & & & & & \\
\hline DEP & 0,12 & 0,04 & 0,21 & 1,00 & & & & & \\
\hline ANX & $\mathbf{0 , 7 8}$ & 0,28 & 0,22 & $\mathbf{0 , 5 8}$ & 1,00 & & & & \\
\hline HOS & $-0,12$ & 0,55 & $\mathbf{0 , 6 1}$ & $-0,55$ & $-0,05$ & 1,00 & & & \\
\hline PHOB & 0,19 & 0,01 & $\mathbf{0 , 6 1}$ & 0,38 & 0,31 & 0,23 & 1,00 & & \\
\hline PAR & $-0,55$ & 0,04 & 0,52 & $-0,31$ & $-0,53$ & $\mathbf{0 , 7 6}$ & 0,03 & 1,00 & \\
\hline PSY & $-0,38$ & 0,36 & 0,02 & 0,09 & $-0,19$ & $\mathbf{0 , 5 9}$ & $-0,14$ & 0,34 & 1,00 \\
\hline GSI & 0,37 & $\mathbf{0 , 6 8}$ & $\mathbf{0 , 6 7}$ & 0,38 & 0,51 & $\mathbf{0 , 7 8}$ & 0,46 & 0,29 & 0,34 \\
\hline
\end{tabular}

Note:

- the dark-gray color indicates the value of the correlation below "noticeable" $(r<0,50)$;

- the light-gray - lower than "high" ( $r=0,50-70,00)$;

- with bold type marked the statistically significant values. 
Correlation matrix for groups of psychopathological symptoms (according to SCL-90-R)

for the subgroup of persons with $\mathrm{GSI}=0,51-1,50$

\begin{tabular}{|c|c|c|c|c|c|c|c|c|c|}
\hline & SOM & O-C & INT & DEP & ANX & HOS & РHOB & PAR & PSY \\
\hline SOM & 1,00 & & & & & & & & \\
\hline O-C & $-0,04$ & 1,00 & & & & & & & \\
\hline INT & $-0,53$ & 0,47 & 1,00 & & & & & & \\
\hline DEP & 0,04 & 0,33 & 0,45 & 1,00 & & & & & \\
\hline ANX & 0,28 & 0,40 & 0,05 & 0,24 & 1,00 & & & & \\
\hline HOS & $-0,10$ & 0,41 & 0,34 & 0,45 & 0,42 & 1,00 & & & \\
\hline PHOB & $-0,02$ & 0,43 & 0,23 & 0,32 & 0,44 & 0,63 & 1,00 & & \\
\hline PAR & $-0,31$ & 0,48 & 0,64 & 0,43 & 0,40 & 0,43 & 0,42 & 1,00 & \\
\hline PSY & $-0,23$ & 0,35 & 0,27 & 0,37 & 0,38 & 0,61 & 0,75 & 0,48 & 1,00 \\
\hline GSI & 0,20 & 0,67 & 0,4 & 0,67 & 0,65 & 0,71 & 0,73 & 0,63 & 0,68 \\
\hline
\end{tabular}

Note:

- the dark-gray color indicates the value of the correlation below "noticeable" $(r<0,50)$;

- the light-gray - lower than "high" ( $r=0,50-70,00)$;

- with bold type marked the statistically significant values.

intensity), corresponds to a range of values from 0 to 0,50 ;

- subclinical (discomfort for the given reason present, but not frequent, moderately intense), corresponds to a range of values from 0,51 to 1,50 ;

- clinical (the discomfort for this reason occurs frequently, or is constant, has a high intensity) corresponds to a range of values greater than 1,51.

\section{Results of research and discussion}

The result of the evaluation of the overall level of psychopathological symptoms (regardless of their belonging to a particular group/subscle) according to the severity index of psychopathological symptoms (GSI integrative index) shows the following distribution of study population: the minimum level is $12(12 \%)$ persons, subclinical - $52(52 \%)$ persons, clinical - $36(36 \%)$ persons (table 1).

To further establishing of the psychopathological violations structure, the

Table 4

Correlation matrix for groups of psychopathological symptoms (according to SCL-90-R) for the subgroup of persons with $\mathrm{GSI} \geq 1,51$

\begin{tabular}{|r|r|r|r|r|r|r|r|r|r|}
\hline & SOM & O-C & INT & DEP & ANX & HOS & PHOB & PAR & PSY \\
\hline SOM & 1,00 & & & & & & & & \\
\hline O-C & 0,27 & 1,00 & & & & & & & \\
\hline INT & 0,23 & 0,09 & 1,00 & & & & & & \\
\hline DEP & $\mathbf{0 , 4 3}$ & 0,29 & $\mathbf{0 , 7 6}$ & 1,00 & & & & & \\
\hline ANX & $\mathbf{0 , 5 4}$ & $\mathbf{0 , 3 8}$ & 0,13 & 0,33 & 1,00 & & & & \\
\hline HOS & $-0,19$ & $\mathbf{0 , 3 3}$ & 0,02 & 0,11 & 0,29 & 1,00 & & & \\
\hline PHOB & 0,08 & 0,07 & 0,13 & $-0,27$ & 0,11 & $-0,13$ & 1,00 & & \\
\hline PAR & $-\mathbf{0 , 3 3}$ & $-0,29$ & $-0,05$ & $-0,09$ & 0,17 & $\mathbf{0 , 5 3}$ & 0,09 & 1,00 & \\
\hline PSY & $-0,27$ & $-0,23$ & $-0,28$ & $-0,27$ & 0,26 & $\mathbf{0 , 5 6}$ & 0,11 & $\mathbf{0 , 8 6}$ & 1,00 \\
\hline GSI & $\mathbf{0 , 3 9}$ & $\mathbf{0 , 3 4}$ & $\mathbf{0 , 4 7}$ & $\mathbf{0 , 5 6}$ & $\mathbf{0 , 7 0}$ & $\mathbf{0 , 6 2}$ & 0,17 & $\mathbf{0 , 5 0}$ & $\mathbf{0 , 4 6}$ \\
\hline
\end{tabular}

Note:

- the dark-gray color indicates the value of the correlation below "noticeable" $(r<0,50)$;

- the light-gray - lower than "high" ( $r=0,50-70,00)$;

- with bold type marked the statistically significant values. 
population of a study was divided into groups, according to the GSI values.

Theabove-mentioneddistribution ofcontingent corresponds to the model of understanding of different groups of psychopathological manifestations severity as different stages of a single psychopathogenetic process.

Thus we obtained 3 matrices of correlation coefficients for different groups of psychopathological symptoms (according to SCL-90-R) for 3 groups of persons with different $\mathrm{GSI}$ values (GSI $\leq 0,5 ; \mathrm{GSI}=0,51-1,50 ; \mathrm{GSI} \geq 1,51)$. Obtained data is shown on tables 2-4.

Analysis of the correlation relationships between the GSI index and all groups of psychopathological symptoms indicates that the severity of mental disorders in this (initial) stage of psychopathogenesis depends mainly on the group of symptoms of hostility, with which there is a high correlation $(r=0,78)$. Secondary factors are obsessive-compulsive symptoms $(r=0,68)$, symptoms of interpersonal sensitivity $(r=0,67)$ and anxiety symptoms $(r=0,51)$.

Thus, it is established that at the initial stage of the development of psychopathological disorders:

a) the dominant set of psychopathological symptoms are associative disorders and dysphoria, the data of the group of symptoms have a mutually reinforcing effect that corresponds to a typical psycho-organic complex; b) associative disorders and dysphoria are limiting the manifestations of anxiety and depression, which indicates the presence of antagonism between the psycho-organic and patho-affective symptoms with the domination of the psycho-organic circle of symptomes, what corresponds to the mechanism of "forced normalization";

c) psycho-vegetative disorders have complex genesis, but only partly they are a somatic correlation of anxiety, the level of psychogenic disorders is reduced due to the antagonism of anxiety with associative disorders;

d) obsessive-compulsive disorders are associated with manifestations of dysphoria and have a similar level of manifestation; in most observations, they are represented by pseudoobsessive phenomena, that are realized as a reminding's of irritating objects (a vicious circle of amplification of both groups of symptoms).

In this GSI-group $(0,51-1,50)$ the analysis of the correlation links of GSI shows that at this stage to the pool of symptoms that provide the severity of the condition added hostility $(r=0,73)$ and phobic symptoms $(r=0,71)$.

Thus it is established that at the intermediate stage of the development of psychopathological disorders:

a) pathoaffective symptoms (anxiety and depression) are subject to associative disor-
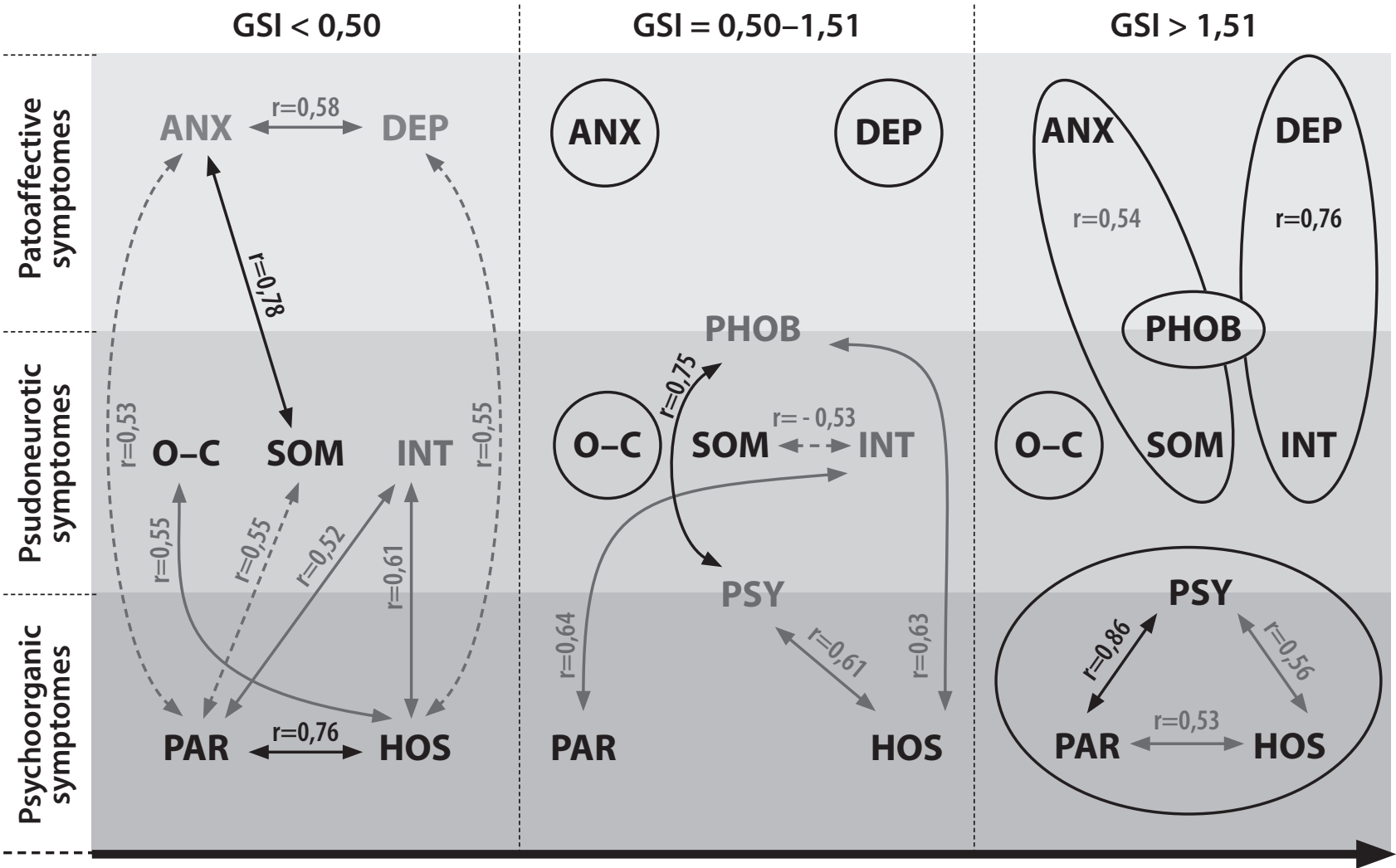

Syndromokinesis

Fig. Model of psychopathogenesis of nonpsychotic mental disorders in the contingent. 
ders and dysphoria, become subtotal and become isolated (they do not show any correlations);

b) the greatest influence on the general severity of manifestations is made by phobic symptoms associated with the loss of critical assessment of their own state (psychoticism) and dysphoria that corresponds to atypical panic attacks;

c) associative violations are the main determinant of social maladaptation (interpersonal sensitivity), but the latter is reduced when the level of psycho-autonomic violations is increased; this may correspond to the adaptation in the social stratum of dependent persons arising from the background of the community of somatic symptoms;

d) obsessive phenomena lose any contacts with dysphoria and become an isolated phenomenon that has a subtotal representation, indicating the trigger role of dysphoria in the genesis of this class of phenomena.

At this stage $(\mathrm{GSI} \geq 1,51)$ analysis of correlations of different groups of psychopathological symptoms with GSI shows that the severity depends mainly on the anxiety $(r=0,70)$, depression $(r=0,56)$, hostility $(r=0,62)$ and paranoyality $(r=0,50)$. It is noteworthy that the influence of symptoms phobic, psychotic and obsessive-compulsive phenomena had been lost.

Thus it is established that at the final stage of the development of psychopathological disorders:

a) all groups of symptoms are consolidated into isolated symptomatic complexes: anxiety and psycho-vegetative disorders, depression and interpersonal sensitivity, associative disorders, dysphoria and psychoticism, isolated phobic symptoms and isolated obsessive-compulsive symptoms; b) symptomatic complexes exist in parallel in the mode of coexistence (in contrast to the comorbidity, they do not interact with each other);

c) all symptomatic complexes are present in all patients at this stage of development of psychopathological disorders, but have fluctuations in the level of manifestations from subclinical to clinical.

d) the general severity of psychopathological manifestations is determined by the symptoms of anxiety.

\section{Conclusions}

The analysis of the correlations between separate groups of psychopathological symptoms was performed according to the SCL-90-R data. Modes of structural and dynamic organization of all groups of symptoms, as well as their complexes, have been identified in 3 stages of their development.

All groups of symptoms are considered in the context of the three classes of disorders: pathoaffective (anxiety and depression symptoms), pseudoneurotic (obsessivecompulsive phenomena, psycho-vegetative symptoms and self-perception violations) and psychoorganic ones (associative violations, paranoyality and hostility) and 2 groups of symptoms as intermediate phenomena - phobic symptoms (intermediate between pathoaffective and pseudoneurotic) and symptoms of psychoticism (intermediate between psychoorganic and pseudoneurotic).

According to the results of the assessment of the correlation dynamics of certain groups of symptoms, a model of psychopathogenesis of non-psychotic mental disorders in persons undergoing substitution therapy of addiction has been constructed.

\section{References}

1. Trujols J. Patient perception of methadone dose adequacy in methadone maintenance treatment: The role of perceived participation in dosage decisions / J. Trujols, F. González-Saiz, M. J. Manresa // Patient Education and Counseling. - 2017. - Vol. 100, № 5. - P. 981-986.

2. Барановский Н. А. Социальная профилактика наркомании среди молодежи / Н. А. Барановский // Социологический альманах. - 2017. - № 8. - С. 115-126.

3. Pharmacogenomics of methadone maintenance treatment / A. A. Somogyi, D. T. Barratt, R. L. Ali, J. K. Coller // Pharmacogenomics. - 2014. - Vol. 15, № 7. - P. 1007-1027.

4. Цыганков Б. Д. Подходы к лечению абстинентного, постабстинентного состояния наркологических больных / Б. Д. Цыганков, С. А. Шамов, М. Н. Земсков // Росс. мед. журн. - 2013. - № 4. - С. 32-36.

5. Wang G. Y. Methadone maintenance treatment and cognitive function: a systematic review / G. Y. Wang, T. A. Wouldes, B. R. Russell // Current Drug Abuse Reviews. - 2013. - Vol. 6, № 3. - P. 220-230.
6. Scaling up methadone maintenance treatment for opioid-dependent prisoners in Iran / M. Farnia, B. Ebrahimi, A. Shams, S. Zamani // International J. of Drug Policy. - 2010. - Vol. 21, № 5. - P. 422-424.

7. Predictors of non-adherence to methadone maintenance treatment in opioid-dependent individuals: implications for clinicians / P. Roux, C. Lions, L. Michel [et al.] // Current Pharmaceutical Design. - 2014. - Vol. 20, № 25. - P. 4097-4105.

8. Incarcerated intravenous heroin users: predictors of post-release utilization of methadone maintenance treatment / H. C. Lin, P. W. Wang, Y. H. Yang [et al.] // J. of Addictive Diseases. - 2016. - Vol. 35, № 2. - P. 109-118.

9. Гребенюк А. А. Клинико-психологический анализ непсихотических психических расстройств у бывших участников программы заместительной поддерживающей терапии и их влияние на мотивацию к прохождению медицинской реабилитации / А. А. Гребенюк // Наркология. - 2016. - № 6. - С. 72. 